\title{
What is the Meaning \\ of Becoming a Parent? \\ From Langeveld to the Good Parent
}

Suzanne Schulz

University of Alberta

Before turning to the question posed, "What is the meaning of becoming a parent?" it is important to note that the epistemological foundations of inquiry into issues of gender both inform and delimit our understandings of what it means to be a mother or a father. In what follows I shall attempt to make explicit how differing fundamental assumptions expand our general breadth of knowledge yet, contextualized within a particular sociohistorical situation, how the observer is only partially able to transcend the sociohistorical situatedness of her or his own experience. To begin, I myself am a woman who calls herself a feminist, and this view of gender inquiry, this situatedness of my experience, defines my response to the question "What is the meaning of becoming a parent?"

\section{Form and Function}

In considering "what is the known," I am of the view that methodological concerns are influenced by fundamental assumptions about form and function. These assumptions establish the relative importance to investigation, the definitive effects, and the terms of the form-function relationship. Up to the present time the relationship of function to form has been explained only on the basis of certain undefined and ambiguous entities such as vital factors, morphogenetic fields, and genetic programs (Sheldrake, 1987). That the connection of form and function cannot be known and explained in the same sense that, say, biological processes, genetic coding, and protein synthesis can be known delimits the grounds of our inquiry into gender and gender relations. How we will think about this unspecified relationship remains within the realm of our speculations, although we might well reflect on the basic assumptions that sustain our thinking.

Various ideas on form and function not only respond to the difficulties in establishing a connection, but also reflect the particular social location of the respondent. For example, a determination on the starting point of investigation must be made. Shall we take biological function or sociocultural form, as the vantage point from which to describe our view of the form-function relation? More importantly, once established, what do we make of our particular stance? Which questions may be addressed while standing on chosen 
ground? Which cannot be addressed?

The impact of these concerns must necessarily be brought to bear on the work of phenomenological research as "the science of description" because any description of "what is" in gender relations "always implies a possible ought" (van Manen 1984, p. 39). This is not to say that a description of what is inevitably reveals what ought to be in mothering and fathering. It is true that scholarly descriptions reveal shades of meaning and human possibilities. But there is also the "meaning of the shades" to consider, which is to say, the consideration of that particular pair of glasses worn by the observer which color her or his view of the thing observed. Consider the statement: "The etymology of the word 'parenting' refers both to 'giving birth to' and 'bringing forth"' (p. 53). Van Manen notes that in its strongest sense the word "parent" is "closely related to the verb "to bear' as in the experience of pregnancy, childbirth, as well as in the experience of parenting as providing spaces that bear children" (p. 53). Situated within the form-function dialectic, women and men enter into and experience this larger project of parenting. It is commonly held that women enter through the experience of pregnancy and men through the experience "of providing spaces that bear children" into a grounded sense of being. But whal if men enter before this point: that is, what if, in a sense, men get pregnant too?

The possibility may appear a frivolous one to us. Yet, does this reveal more about our meanings or our "shades"? Again, it is possible that speculations regarding function and form may be more closely related to spectacles than to what is or ought to be noticed. For if it is assumed that men cannot "give birth" in a full and undivided sense, then shall fathers be considered half-parents... or quarter-parents? Or do we arrive at Langeveld's conclusion that most fathers do not parent at all, only to surmise that men may not be able to parent?

Before I discuss the impact of these concerns on feminist inquiry, I shall first put some interpretive remarks to Langeveld's work. Then, beginning on his ground, I shall move from the question "What is the meaning of being and having a father?" to show in the end why I think it is important to ask, "What is the meaning of becoming a parent?"

\section{If Men Would be Fathers}

For his part Langeveld starts at biological function in a view to gender roles. On this ground he shows how the experience of individual biology determines sociocultural form and the sexual division of labor in procreation. He writes:

A woman is by nature inseparably the mother of her child. She runs away from herself, she runs away from nature and the essence of womanhood if she abandons her child. The man, however, stands apart from the process of inner growth, this pregnancy. The birth completes nothing for him. (Langeveld, 1971, p. 3) 
Consequently, by nature every child has a mother, although it is not the case that every child has a father who is present. According to Langeveld a man must become present to the child, as father, somewhere within the first or second year of life. Up to this point, he has a peripheral role as a "luxury"-a "plus sign" to the primordial parent-child relationship. When Langeveld goes on to state that "a child should have a father," it is recognized as a value judgment quite apart from natural connection.

In Langeveld's view, the man who would be father must make his place within the mother-child intimacy sphere by intently occupying himself with the child. In this way the good father becomes experientally meaningful to the child as an example of trust and an unchangeable and objective mediator of the larger world-the world of the father. On the "deciding word" he announces his presence to the child, initiating sons into responsibility and daughters into the significance of being a woman related to a man. In this the father represents "the mighty forces of adulthood" in a more objective sense than the mother who remains at home. By the same token, the good father symbolizes security and protection. He respects the child's separate selfhood and entitlement to a childhood, particularly in his directed response within the father-daughter relationship. From good fathering issues an experience of continuity in relationships. The good father lives for his children and belongs to them, while protecting his wife in faithfulness.

Written almost 25 years ago, Langeveld's account of fathering is remarkable in that it both supplements a still scanty literature on the subject and touches on many experiences which are the focus of feminist attention. Many feminists would admit it as an absorbing description of "what is" in the childrearing situation, while at the same time finding this order of things a matter for critique and evaluation. Furthermore, even if the original situation where fathers occupy a peripheral role in relation to that of the mother is taken to be a "primitive-naturalistic" given as Langeveld suggests, it remains unclear how men will enter into the parent-child intimacy sphere as good fathers. The entrance is more obvious in the case of a female parent. According to Langeveld's view, beginning in the womb, the dynamic interaction of mother and child enhances and facilitates the development of not just one, but two human beings: mother and child. The changes in, and development of, meanings, values, and world view arise out of the process of a mother bearing and caring for her child. What is not so obvious is how a man will want to and be able to enter into the parenting of his child.

On this account man is "naturally" disconnected from the processes of reproduction and inner growth. Langeveld (1971) notes that most often out of this distancing there emerges in men, not the good father, but "the trappings of patriarchal masculinity" associated 
with careerism, hostility toward the other and community in combat. Citing the "natural" disposition of men to fight and hunt, Langeveld alludes to the biological basis of the masculine response. This functionalist view to life, which is Langeveld's starting point, might yield a poor prognosis for change, and a particularly poor prognosis for the hunted-whether on four legs or two-except that Langeveld adds to the biological fact the matter of subjective experience. It seems that naturally, for Langeveld, has two significances: as pure biological causality, and as in the nature of things. Every parent-child relationship, it seems, is both rooted in biology and culturally determined.

Langeveld presents the imperative of cultural forms as rules and standards which impose order on the conduct of fathers. On this view, parenting for men describes not a way of being, but a decision to assume a role and perform tasks. Out of the context of his own experience, "doing" what is moral according to Langeveld reflects the masculine philosophical tradition of justice, described by Shogan (1986) as the reasoned appeal to cultural and, perhaps, universal principles. Moving one step further away from the essence of the thing (that is, man the hunter) Langeveld (1971) enters the ideological realm and adds Christian principle to this. The man who would be father is identified by his adoption of, and adherence to, these principles. Thus in principle, he accepts the child in his decision to marry, belongs to the child, and is its symbol of security.

What remains problematic is that from his interactionist position Langeveld has been unable to specify how the interaction between a man's biological nature and the form of his conscious self can lead to anything other than its present outcome. According to his own account, external masculine conflict, competition, and aggression become an interiorized struggle for the man who would be father. That the "dominant cultural concept is overshadowed by the 'natural' concept" (1971, p. 9) suggests that one aspect of man wins out in this struggle. And it is not the image of the father.

\section{Men Will be Men}

At the outset Langeveld notes that rules and standards do not sit well with men. Order is imposed, yet to obtain selfish ends it is easily broken. For an example of this, he astutely observes that God the Father is an Ideal created for fathers by men. This creation allows men to have it both ways: on the one front, identification with God the Father validates the power of all fathers and the cultural hegemony of men whereas, on the other front, an appeal to God as the only true father permits men to abdicate responsibility should they wish to do so. Not surprisingly then, despite what might be Christian principle to the contrary, known social experience has it that the primary responsibility for parenting falls not to men but to women. The cultural ideal is thus a biased ideal. It reflects one half of reality 
at most. I say, at most, because it ignores the experience of women and, in addition, may not reflect the desires of many men.

While Langeveld indicates that a healthy spiritual and mental development in children must necessarily involve shared parenting, what will impel men to take part? Langeveld observes that men will be men and that, in their propensity to spend time on themselves rather than on children, they render each new generation of sons more narcissistic than the last. (Consequently, it is difficult to account for the realization of a "possible ought" in parenthood given "pure biological causality.") It is possible that in answer to Langeveld's question "What are we prepared to do?" a man might simply say, "I will do nothing." Would such a response not be in complete accord with man's nature as described?

I would argue that a consideration of assumptions establishing the relationship of function to form lies beyond Langeveld's account. Yet these assumptions are certain to impact not just Langeveld's but any account of gender relationships and parenting. For this reason, the relative importance put to biological function on the one hand, and to sociocultural forms on the other, has led to lively dehate in feminist circles.

\section{Women Focus on Form}

At the time of Langeveld's writing the world of the parent was clearly open to women, yet, impelled and enabled by their own sociohistorical location, it was into the world of the father that women desired to enter (Breines, 1985; Goldner, 1985). Minimizing sexual difference, feminists of the '60s argued that the nexus of reproductive capacities and childcare responsibilities was not self-evident for either men or women. Rather, starting at an analysis of sociocultural forms, feminists asserted that the appeal to biological imperatives was merely a social construct which confined women to the home (Goldner, 1985). They reasoned that once the umbilical cord to this form of parenting was cut, women would leave home, enter the public domain, and be primarily responsible for childcare no longer.

Interestingly, Jagger (1985) shows how feminists of the period critiqued childrearing practice as a social form, yet, in exchange for adoption into the world of fathers, how women attended to other male standards and ideals as the norm. Thus women joined their efforts to achieving equality with men, by speaking the same language - of liberal ideals. Shogan (1986) notes the liberal humanist stance equated feminist ethics with political action on behalf of women: "to do' feminist ethics was to be actively involved in working to counter social injustice suffered by females because of their sex" (p. 1). These articulate women making their way into the educational institutions and professions argued that any gender difference could be traced to the differential educational opportunities of 
women relative to men, and would disappear as efforts were made to redress this imbalance. Asserting that women, as rational beings, are entitled to exactly the same rights as men, they recommended that sexual differences be "deinstitutionalized" and that social and legal definitions ignore sexual difference "in any other than a strictly reproductive context" (Jagger, 1985, p. 2). Of course, the expectation was that as women gained access to the public realm men naturally would enter the domestic sphere.

\section{The Vision of a Transformed Society: Where it has Led}

It is significant that the vision of a transformed society later directed many feminists back to biological fact. By the mid '70s women had noticed that, despite their concerns with establishing themselves in the public realm, at the domestic level things had not changed that much. Women enthusiastically entering the professions found that mothering entailed juggling two careers. And whereas shared parenting might have been a solution, it was discovered that in general men just did not want to be involved (Goode, 1980).

A woman's perspective began to inform accounts of family life, motherhood, and living with a man or a father. Chodorow's (1978) writing is of this genre and agrees with Langeveld's (1971) work in several respects. For example, she also observes that a father does not experience an original oneness with the child and must become present to the child later - at the verbal level - at the time when a father is understood by the child both in his power to define the larger world and to consciously sex-type the child along traditional gender role lines. Where her account would not agree with Langeveld's is with reference to the origins of a child's sense of continuity in relationships. Chodorow shows how the child's inner sense of the continuing presence of the good parent develops in relationship to mothers, and not fathers. She holds that the seed of this inner sense is planted within the mother-child intimacy sphere, unfolds out of this early relationship, and gives birth to all other relationships of love. This is especially so for daughters who grow up developing their mother's relational capacities, openness, and the desire to be mothers themselves. On the other hand, according to Chodorow, a father introduces discontinuity into the lives of children, and particularly into the lives of sons. Growing into the world of the father demands that the son separate from his mother as he moves toward autonomy and independence. According to this view, sons grow up by repressing their needs and capacities for nurturance. They close themselves off from others emotionally, and at the same time they deny the feminine in themselves and devalue its appearance in others.

Feminists have begun to explore more fully exactly what it is that fathers do pass on to their children. These women note that father is 
not so much a plus sign but, rather, in identification with the Almighty Ideal, father is "oneness." Mother and child are minus that (Irigaray, 1980). Borrowing from Langeveld (1971), this order "easily means the same thing ... as dominance" (p. 9.). Spender's (1985) research illustrates how men "do" dominance in conversation. She finds, for example, that most of the "deciding words" in the dictionary are masculine rather than feminine in origin and that "there is no term for normal sexual power in women" (Hage, cited in Spender, p. 175). In addition, books such as Male Practice (Mendelsohn, 1982) have lent an ominous tone to statements such as Langeveld's that the father "makes it possible for the mother to be vulnerable in pregnancy and birth" $(1971$, p. 3).

Drawing on these developments in the late '70s and the ' 80 s, many women are now in agreement with Langeveld on this point: Women are essentially different from men. These women have turned to the female body as the source of lifegiving power and transforming experience. And as more mothers become feminists and feminists become mothers (Goldner, 1985), they question whether it is possible for a woman "to leave her body out" of parenting (Young, 1985, p. 173).

\section{Birthing the Self-Woman Becomes Parent}

For a woman, the meaning of becoming a parent is intimately connected to her biological being. In the birthing experience it is a woman's body that enfolds her, carries her, and bears her into the world of the parent. For the woman who would be parent this experience envelops her within the terrifying fear of pain, the comforting presence of other mothers, the joyful release of birth, the dawning awareness of new possibilities (Bergum, 1986). Bergum writes, "As we birth our children, we, in a sense, birth ourselves" (p. 6). Through the body the conscious form of a woman's thought is trans-formed. Woman becomes parent. Of this experience Kitzinger writes: "Something in me was released. I turned ... towards my child, and since that moment my love has grown so that ... it actually hurts sometimes" (cited in Bergum, 1986, p. 161).

Hartsock (1983) emphasizes that women's later experience of caring for men and children sustains this connection to the human other and to biological nature. Ruddick (1983) believes that the "attentive love" characteristic of maternal thinking is preserved and grows as the mother is "fostering and shaping the growth of a child" (p. 234). The child learns "attentive love" from its mother just as the mother herself is developing it. This particular kind of thinking is not, therefore, the preserve of mothers only, but of anyone who learns and is not separated from this particular kind of nurturant and preservative care. O'Brien (1981) suggests that through knowing that this experience is theirs, potentially or actually, women apprehend a female reproductive consciousness that is life affirming and life 
enriching. Within this context, it is not surprising that the process of a mother bearing and caring for her child is celebrated as important in and of itself and, in addition, as the ground for a renewed society.

\section{For Men, What is the Meaning of Becoming a Parent?}

O'Brien's (1981) claims that the reproductive consciousness is unavailable to men and that, as a consequence, the form of a man's conscious thought and culture-making activities produces dualism and separation. At the same time, creative intellectual activity allows men to experience a second birth within a spiritual realm, transcending the biological realm of women. Here we come full circle to Langeveld: Men are the sorry victims of their biology and, in turn, women and children are made victims by men. This interpretive end point is supported both by Langeveld's observations and by an extensive literature outlining the violence and abuse directed by men against women and children (Rush, 1980; Ward, 1984). As an account of "what is" this certainly points to women, rather than men, as the future hope of this planet. However, making the thing observed a sufficient description and necessary outcome of biological imperatives, I think, might be called in question.

We could draw a different conclusion, for instance, if it were shown that man's separation from the process of giving birth is another example of the discontinuity within men's lives that is not necessarily rooted in biological fact. Then the poetry, myths, and dreams of men might be viewed differently: not as expressions of male jealousy (though this may be entailed) but as the conscious expressions of a deeper meaning rooted in the biological being of men; not as ideological expressions of the male order of things (though this may be entailed) but rather as the expression of the wishes, wants, and desires of men.

Then the following could be revealed as man's quest for the life-generating aspects of the self and the father: The Son only begotten of God the Father gives birth to man (John 1:12-14); Goethe's (1930) Faust is saved by the feminine aspect that is Gretchen; Freud's (1939) Moses integrates the life-generating and "masculine" aspects of the male self in a final symbolic unity.

If the power of these images for men is not denied, then bringing this to bear on the meeting of cultural forms with my own sociohistorical experience, I am led to believe that biological man is actually something more then a relic of the Stone Age. I arrive at the final question posed, "For men, what is the meaning of becoming a father?"

The literature on fathering remains sparse, with most of it discussing the father role or the father figure (McKee \& O'Brien, 1982). Establishing father as protector, provider, or married man (Owens, 1982) appears to mark a reordering of relationships. Traditionally, for a man pregnancy has announced a shift in position, away from the center of his partner's attention (Chodorow, 
1978) to a place on the periphery of the mother-child union (Langeveld, 1971). Not only does the woman's attention turn to the child, but as the man's attention turns to his partner he is vulnerable to feelings of "helplessness" or of "being an encumbrance" (Brown, 1982), p. 105). Within this context men impose order-with order, by order, and in order to know themselves as men and fathers (Richman, 1982). It seems to me that roles do afford an ordered protection from this pregnancy, this inner growth. The flip side, of course, is that if a man does not experience this inner growth in the process of pregnancy, to assume a father role later may be difficult work and, for many men, a task to be avoided where possible. Further, the father playing a role will not a good parent make. And simply urging a man to "do a better job of it" reasserts the natureculture split presupposed in fathering and, therefore, this strategy cannot effectively challenge the present order of things. As we have seen, becoming a parent is "a way of being" in touch with others and the life-generating aspects of the biological self. It is a way of giving birth to oneself and to others which will enable the work of caring for a child to be sustained.

Little is known about this process for men during pregnancy; however what is known does not support the notion that "the birth completes nothing" for men, at least not for caring men. So perhaps it would not hurt to focus on such men, and to draw on their experience for the "possible ought."

Stewart and Chester (1982) found in "the TAT measure of emotional adaptation to the environment" that scores of men were lower during pregnancy than after the birth itself. For women it was just the opposite. These researchers "suggest that men may experience the pregnancy as signalling the main transition or change in life, "whereas the women seem to experience the actual birth of the baby as the major transition"' (cited in Osherson, 1986, pp. 132-133). Given this, other researchers suppose that the crises of infertility, miscarriage, and stillbirth may reveal the significant features of a man becoming parent ( $\mathrm{McNab}$, cited in Osherson, 1986; Richman, 1982). For example, Finding Our Fathers (1986) emerged out of Samuel Osherson's journal keeping over the course of several miscarriages and the final birth of a child. He writes of this period for his wife Julia and himself:

The last of four miscarriages was more than two years ago, yet I could still feel the desperation, the loneliness, and the powerlessness of those years. Few experiences have been as powerful and instructive to me... What strikes me now is how much I was centered on Julia and how difficult it was to sort out my own feelings, to accept them. (p. 97)

For Samuel Osherson these events ultimately became a healing experience: 
[They helped me] ... come to terms with my rage and vulnerability ... reevaluate the kind of work I do, why I do it, the role of intimacy and competitive issues in my life, and how I relate to women. (p. 100)

One of the things I learned was that I could let go and experience my feelings of sadness and vulnerability while Julia could be there for me, just as I could be for her. (p. 103)

Richman (1982) notes that we assume men's relationships to the fetus is a secondary one, a commonsense notion based on the fact that it is the woman who physically carries the child, whereas a man does not. Yet this assumption presupposes fixed developmental stages in men and denies their "emotional potentialities" (Richman, 1982, p. 94). In addition, I think it negates the possibility of a unique reproductive consciousness rooted in men's biological being. Of this Osherson writes:

We accomplish the "developmental task" of identifying with our fathers by murdering the feminine within ourselves ... We resolve never to feel that neediness again. (1986, p. 124)

[Yet] watching the lifegiving nature of femininity can stir up a man's wish to be creative in a "feminine way." (p. 134)

I needed to spend a great deal of time ... retracing the sources of warmth and fullness in my life. (p. 137)

He speaks of the need to be comforted and reassured by a man, to know it was all right to be scared, "to care so deeply":

I wanted tactile contact, I suddenly felt an ache to be held, supported, to feel less alone, and I wanted that from a man. (p. 131)

Is it possible for men to imagine comforting each other without fearing homosexuality? (p. 131)

Out of this experience, for Osherson a connectedness emerged-a sense of connection with his own father and with other fathers "down through the generations and back again" (p. 167).

On Osherson's account it is difficult to hold to an innate disconnection of men from the reproductive consciousness. Many of his notes resonate with the clarity of Bergum's writing, though they are uniquely the description of a man's experience. This experience envelops him within a painful fear, the relationship of his own body to pain, the need to be held, to be carried through the experience by other men, the joy of birth, and the sense of connection to other fathers gone before and still to come. In a sense, Osherson also gives birth to the child and to the self. In doing so, he discovers the meaning of becoming a parent.

I think that if there was ever an experience needing to be explored more widely it is the one described by Osherson-an inquiry by men, for men, and in the end, for us all. Note, however, that this is 
not an appeal to men to further define and dominate the reproductive experience of women. This is women's own. Rather, it urges men to look at the form of their own experience of parenthood in its connectedness to the lifegiving aspects of the biological male self. I think it is important to make this connection in the case of both women and men to find, then to live out, the meaning of becoming a parent.

\section{References}

Bergum, V. (1986). Birthing pain. Lifeworld Editions: Texts of the Body, pp. 1-7.

Breines, W. (1985). Domineering mothers of the 1950's: Image and reality. Women's Studies International Forum, 8(6), 601-608.

Brown, A. (1982). Fathers in the labor ward: Medical and lay accounts. In L. McKee \& M. O'Brien (Eds.), The father figure (pp. 104-119). New York: Tavistock Publications.

Chodorow, N. (1978). The reproduction of mothering. Berkeley, CA: University of California Press.

Freud, S. (1939). Moses and monotheism (K. Jones, Trans.). New York: Knopf. (Original work published 1937)

Goethe, J.W.V. (1930). Faust (A. Raphael, Trans.). New York: Herilage Press. (Original work published 1832)

Goldner, V. (1985). Feminism and family therapy. Family Process, 24 (1), 31-47.

Goode, W.J. (1980). Why men resist. Dissent, 27(2), 181-193.

Hartsock, N. (1983). Money, sex and power: Toward a feminist historical materialism. New York: Longman.

Iragaray, L. (1980). When our lips speak together (C. Burke, Trans.). Signs, 6(1), 69-79.

Jagger, A.M. (1985). Women:Different but equal? Unpublished manuscript, Douglas College, Rutgers University, NY.

Langeveld, M.J. (1971). What is the meaning of being and having a father? In Erziehungskunde und Wirklichkeit (M. van Manen \& P. Mueller, Trans.) (pp. 1-12). Braunschweig: G. Westeman Verlag. (Original work published 1963)

McKee, L. \& O'Brien, M. (Ed.). (1982). The father figure. New York: Tavistock Publications.

Mendelsohn, R.S. (1982). Male practice. Chicago: Contemporary Books.

New American Standard Bible. (1975). Chicago: Moody Press.

O'Brien, M. (1981). The politics of reproduction. Boston, MA: Routledge \& Kegan Paul.

Osherson, S. (1986). Finding our fathers. New York: Free Press.

Owens, D. (1982). The desire of father: Reproductive ideologies and involuntary childless men. In L. McKee \& M. O'Brien (Eds.), The father figure (pp. 72-86). New York: Tavistock Publications. 
Richman, J. (1982). Men's experiences of pregnancy and childbirth. In L. McKee $\&$ M. O'Brien (Eds.), The father figure. New York: Tavistock Publications.

Ruddick, S. (1983). Preservative love and military destruction. In J. Trebilcott (Ed.), Mothering: Essays in feminist theory (pp. 213-262). Totowa, NJ: Rowman and Allenheld.

Rush, F. (1980). The best kept secret. New York: McGraw-Hill.

Sheldrake, R. (1987). A new science of life. London: Palladin Books.

Shogan, D. (1986, June). What is 'feminist ethics'? Paper presented at the Meeting of the Canadian Women's Studies Learned Society, Winnipeg, MB.

Spender, D. (1985). Man made language (2nd ed.). Boston, MA: Routledge \& Kegan Paul.

van Manen, M. (1984). Practicing phenomenological writing. Phenomenology + Pedagogy, 2(1), 36-69.

Ward, E. (1984). Father daughter rape. London: Women's Press.

Young, I.M. (1985). Humanism, gynocentrism and feminist politics. Women's Studies International Forum, 8(3), 173-183. 